\title{
А. Зукер
}

ORCID: 0000-0002-4382-5112

arnaud.zucker@univ-cotedazur.fr

Университет Лазурного берега

(Франиия, Нициа)

\section{СУЩЕСТВУЕТ ЛИ «РАЦИОНАЛЬНЫЙ МЕТОД» В МИФОГРАФИИ? \\ ПРИМЕР МИФОГРАФА ПАЛЕФАТА (IV В. ДО Н. Э.)}

\begin{abstract}
Аннотация. В статье вначале будет обсуждаться dоха относительно происхождения экзегезы в Древней Греции, существования мифологического мышления и использования терминов «аллегория» и "рационализация», которые неверно применялись исследователями в отношении античных мифологических текстов. Затем будут представлены уникальные свойства труда Палефата, являющегося единственной систематической попыткой перенести/перевести греческие мифы в их историческое окружение. Палефат не разделяет обвинений во лжи, которые традиционно сопровождали мифы в античности, в том числе в критике ранних поэтов. По его мнению, миф обусловлен языком и его неоднозначностью (рассказ первых свидетелей определенных событий реинтерпретируется слушателями). Подобная изначальная семиологическая этиология заставляет Палефата рассматривать миф как палимпсест и переписывать мифы, следуя привычному (и потому зачастую тусклому) сценарию в идеализированном примитивном культурном контексте. Такая переработка способствует возникновению новой версии мифа и парадоксальным образом укрепляет народную веру в его «правду» - вероятно, в соответствии с намерением автора.
\end{abstract}

Ключевье слова: античность, мифография, Палефат, рационализм, аллегория, экзегеза, мифология, древнегреческая литература

Для иитирования: Зукер А. Существует ли «рациональный метод» в мифографрии? Пример мифографра Палефата (IV в. до н. э.) // Шаги/Steps. Т. 6. № 2. 2020. C. 33-52. DOI: 10.22394/2412-9410-2020-6-2-33-52.

Статья поступила в редакиию 15 декабря 2019 г. Принято к печати 4 ббевраля 2020 г. 


\title{
A. Zucker
}

University of Côte d'Azur

ORCID: 0000-0002-4382-5112

arnaud.zucker@univ-cotedazur.fr

(France, Nice)

\section{IS THERE A “RATIONALIST METHOD” IN MYTHOGRAPHY? The case of Palaephatus, A $4^{\mathrm{TH}}$ CENTURY BCE MYTHOGRAPHER}

\begin{abstract}
This paper first critically discusses the doxa concerning the origin of exegesis in Greece, the existence of so called "mythical thought", and the use of the terms allegory and rationalization, which are misused by researchers when applied to ancient texts related to mythology. There is no special approach that can be called rationalis t and set apart from other exegetical practices. We try to propose another characterization of the mythographic tradition: it distinguishes between the allegorical interpretation of a (usually poetic) text, which conceives of myth as an intentional disguise, and the "allomythic" reformulation of a (popular) narrative, which conceives of myth as the distortion over time of a historical experience. Then we discuss the singular features of Palaephatus' work - the only systematic attempt to transpose/ translate Greek myths into historical screenplays. The ancient author does not adopt the suspicion of lying that traditionally weighs on myths in antiquity, and that is accompanied by criticism of poets. It is language and its ambiguities that constitute, according to him, the main root of the myths: the account given by the first witnesses of certain events was misinterpreted by the listeners. This semiological etiology is original, and leads Palaephatus to seek the palimpsest of myths and to propose a rewriting of the myth (remythification), following a familiar (and often dull) scenario, in an idealized primitive cultural context. This recycling process gives rise to a new version of the myth and paradoxically reinforces - as is probably the author's intention, - the popular belief in its "truth".
\end{abstract}

Keywords: antiquity, mythography, Palaephatus, rationalism, allegory, exegesis, mythology, Greek literature

To cite this article: Zucker, A. (2020). Is there a "rationalist method" in mythography? The case of Palaephatus, a $4^{\text {th }}$ century BCE mythographer. Shagi / Steps, 6(2), 33-52. (In Russian). DOI: 10.22394/2412-9410-2020-6-2-33-52.

Received December 15, 2019

Accepted February 4, 2020 


\section{Введение}

$\mathrm{K}$

ак представляется, целью конференции, на которой прозвучал доклад, легший в основу данной статьи, было коснуться вопросов, связанных с историзмом идей, с идеологической инструментализацией мифов или по крайней мере конъюнктурной практикой некоторых толкований (экзегезы) в области мифологии или критики мифа. Именно с этой точки зрения я буду рассматривать одно из важных направлений в критике мифа, рано появившееся в античной традиции, которое туманно и неточно определяется как рационализм. Я обращусь к трем вопросам: 1) существует ли общепризнанная толковательная практика, которую можно назвать раци онал и с и ч е с ко й и которая используется целенаправленно; 2) можно ли считать использование этой практики методологией; и, наконец, 3) насколько такой явный сторонник этой практики, как Палефат, преуспел в ее исследовании и в пересмотре мифов. На первые два вопроса я отвечаю отрицательно (впрочем, второе нуждается в дополнительном объяснении). Что касается третьего, я надеюсь продемонстрировать радикализм практики Палефата и далее сделать выводы о ее историчности или возможном влиянии социально-политического контекста на ее теоретическую программу.

\section{Общий контекст}

\section{Происхождение экзегезы}

Начну с соображений о возникновении экзегезы и самой категории «мифологического мышления». Как утверждают антропологи, мифы — результат длительной последовательной устной традици и. Большинство греческих авторов классического периода видели это иначе: мифы - продукт творчества отдельных поэтов. Это привычное занятие позволяет эпическим, лирическим или драматическим поэтам пе ре иначи вать смысл традиционных сюжетов, которые они охотно воспринимают и передают. Такое личное (и персонифицированное) происхождение вариантов объясняет разнообразие мифологических версий, оспаривание авторства и... развитие экзегезы ${ }^{1}$. Таким образом, за мифами стоят авторы (не анонимная народная традиция), даже если их сюжеты впоследствии становились общественным достоянием. Это основное положение не отменяет того обстоятельства, что начиная с классического периода и далее поэтические повествования и фольклорная традиция зачастую воспринимались как некое совокупное творчество, порожденное поэтами вообще или, что еще более расплывчато, — традицией.

Поразительно, что в античной критике мифологии очень мало нападок на разнообразие версий или на отдельных авторов (т. е. поэтов) за их предпочтение собственных вариантов, поскольку именно так функционируют мифы

${ }^{1}$ См. у Палефата, который обвиняет поэтов во многих отношениях. См. Ксенофан F B 10 DK: «Свои знания с самого начала греки переняли от Гомера». 
и таковы правила игры. Если в исторической традиции многие авторы (например, Иосиф Флавий или Лукиан) $)^{2}$ считали противоречивость версий недопустимой и видели в ней повод для недоверия историкам, для традиции мифологической (в случаях, когда ее можно отделить от исторической) такие расхождения вовсе не считались криминалом ${ }^{3}$. Иными словами, разногласие мифологических версий не являлось недостатком и не считалось показателем фантастичности мифа или поэтического вымысла. Противоречия в происхождении героя или его деяний никогда не вызывали подозрений в существовании или в историчности действующего лица. Греческий урок именно в том и состоял, чтобы уметь гибко использовать разнородные мифологические версии, удовлетворяться их множеством и спокойно существовать в этом «облаке» разнообразных вариантов ${ }^{4}$.

В соответствии с современным научной т ра д и и ей, разделяемой большинством ученых ([Buffière 1956; Pépin 1958; Brisson, Jamme 1996] и др.), экзегеза родилась из стремления (и необходимости) спасти Гомера от нападок рациональной критики. По мнению Ж. Пепина [Ре́pin 1958], рационализм появляется в западной интеллектуальной мысли VI в. до н. э. в качестве стимула, побуждающего защитников Гомера изобрести противоядие в виде аллегорезы. Концепция, лежащая в основе этого сценария, понятна, устойчива и в какойто степени традиционна: по определению участники культурной трансмиссии так или иначе стараются продлить жизнь доставшегося им законного наследства. Таким образом, ученые, мыслители, философы, педагоги или грамматики уже в силу самой своей профессии призваны беречь традицию и укреплять свершения прошлого. Легче воспроизводить традицию, нежели соперничать с нею, и все же...

Все же можно представить и другую версию происхождения герменевтики: она является естественным продуктом соревн о вания между разнородными версиями одной и той же истории или события у разных поэтов. Интерпретация и критика были не делом рук комментаторов Гомера или его сторонников (а этот поэт отнюдь не был одинок), но результатом столкновения целого ряда противоположных версий. В соответствии с такой интерпретацией происхождение экзегезы следует искать в самой природе эпического творчества и заведомой гибкости повествования. Постоянно сталкиваясь с несоответствием версий, комментаторы (или рапсоды) должны были выработать способы оценки или некую методологическую стратегию - для того, чтобы примирить не Гомера с законами природы, а различные версии друг с другом, сведя их воедино на новом, более высоком уровне. Поскольку на основе рационального объяснения отвергать некоторые версии мифов в пользу однойединственной было нелегко, первые толкователи пытались предложить их разумное обоснование с помощью либо оригинального п а л и м п с е с т н о го т о л ко в а н и я (символического или предполагающего искажение с течением времени), либо поиска объединяющего варианта (подобный отбор и связанные с ним разногласия характерны для некоторых м ифогра фов).

${ }^{2}$ Cм. Joseph. Ap. I.5.23-25; Lucian. Hist.Conscr.

${ }^{3}$ См. Joseph. Ap. I.5, против Diod. Bibl. IV.1.2.

${ }^{4}$ Cм. Diod. Bibl. IV.8.3-4; [Veyne 1983; Bourveresse 2007]. 
В любом случае такой критический подход к мифологии, зародившийся в поздний архаический период, предполагает сосуществование двух уровней, двух процессов, которые в равной степени совмещают оспаривание традиции и ее защиту. При пересмотре сюжета или подробностей изложения, а порой и его цензуре лучше сохранить дух или ценность текста или сюжета н а дру гом уровне. Критическое толкование - это интеллектуальный процесс, в котором соединяются опровержение и обновление изначального замысла.

На самом деле критика мифа или религиозных воззрений не связана с укреплени ем разумного начала (какой античный текст выказывает больше нетерпимости по отношению к богам и поэтическому вымыслу, чем «Илиада»?). Критицизм - это стремление к взаимопониманию, а не к уничтожению мифов. Он столь же нарушает традиции, сколь и сохраняет их, поскольку напоминает о них и приспосабливает их к новым условиям. Чтобы миф оставался живым, необходимо дать ему новую жизнь. Этот существенный момент следует воспринимать как парадоксальную, но априори неизменную особенность любой экзегезы, любого действия, сочетающего критику и переиначивание, когда опровержение выступает в функции защиты. Среди определений, которыми греки обозначали этот процесс, стоит назвать $\theta \varepsilon \rho \alpha-$ $\pi \varepsilon i \alpha$ (подразумевающее значения 'чинить' и 'лечить') и даже более характер-

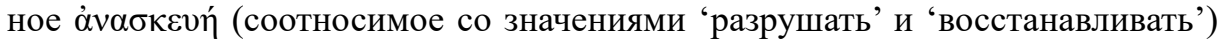
[Zucker 2016: 61]. Критическое толкование — это форма восстановления эпической речи в послеэпический период — в эру письменной литературы.

Правда, представляется, что в более широком смысле в архаическую эпоху существовал род предварительного состязания между эпической «литературой» и... всем остальным: против эпоса выступает и лирика, и трагедия. Эта ситуация создает условия и дает толчок дальнейшему литературному творчеству. Из «Поэтики» Аристотеля очевидно одно: это не различение и не определение литературных жанров, но свидетельство того, что эпическая поэзия предстает определенной исходной в ехой. Это не один из литературных жанров, но скорее самое сердце и об и талище литературы - литературы в целом и языка как ее непосредственной функции. И, вероятно, лирические поэты (это видно хотя бы на примере элегий Ксенофана из Колофона), противодействуя эпосу, уже критиковали мифы; во всяком случае л о го гр а фы и историки уже вменили это себе в обязанность, в raison d'être, и именно так проза впервые обрела свою идентичность.

\section{Легенда о «мифологическом мышлении»}

Нелегко освободиться от предубеждения, что между VIII и II вB. до н. э. интеллектуальная деятельность греков снизила накал ге н иального в д о х н о в ен и я и в то же время обрела ту скл ую я с н о сть. В ней как будто происходил кардинальный поворот, одобренный и признанный сторонниками «греческого чуда», среди которых большинство тех, кто вроде бы открыто критиковал эту идею, включая самого Ж.-П. Вернана [Vernant 1962; Gernet 1983]). Однако было бы верхом наивности полагать, что в VIII в. до н. э., как и в VI в. до н. э., м и ф о лог и че с ко е сознание, которое воспринимало традиционные сюжеты буквально, постепенно оказалось перед запросо м на 
ра ц и о нальн о сть, задачей которого было привести все к единому знаменателю, втиснуть эти истории в нужные «реалистические» пропорции. Это отвечает нашему пристрастию к ранжированию всего и вся, нашей приверженности унылым эволюционным образцам, однако искажает целостную картину античной интеллектуальной деятельности и ее результатов. Здесь важно хотя бы кратко задержаться на этой воображаемой схеме, поскольку она взаимосвязана и с нашим представлением об античной экзегезе. По правде говоря, того, что называется «мифологическим мышлением», которое рассматривалось в качестве дологического этапа мышления («архаического» в нашей культуре и «примитивного» в других), несмотря на всю возвышенность этого понятия, изобретенного современными антропологами, на деле не существует вовсе. Или, наоборот, если и существует, то существует всегда и везде. Это лишь фигура речи, но никак не строгое или осмысленное понятие - будь то с точки зрения антропологии или психологии. В 1981 г. этот тезис, высказанный в «Изобретении мифологии» М. Детьена [Detienne 1981], стал предметом пространной полемики между ним и К. Леви-Стросом. Выражение «мифологическое мышление» имеет тенденцию противопоставлять один способ мышления другому, более совершенному или более современному и, кроме того, выводит за рамки рассмотрения самое существенное, а именно человека мифологической эпохи, который предположительно мыслил и наче.

В 1996 г. 150 исследователей встретились в Бристоле, чтобы обсудить эту устаревшую идею. В соответствии с похожей идеей, выдвинутой в 1940 г. В. Нестле [Nestle 1940], человечество предположительно двигалось «от ми фа к рациональности»; той же логике следовали У. К. Ч. Гатри в своей «Истории греческой философии» [Guthrie 1962-1981] и его последователи, утверждавшие, что греческая философская мысль между 600 и 300 г. до н. э. развивалась «от мифопоэтического взгляда на мир к рациональному» [Buxton 1999: 2]. Эта эволюционная перспектива сделала возможным представить критику мифа формой освобождения и... научного прогресса. Во введении к сборнику статей по материалам упомянутой конференции Бакстон, выдвинув ряд возражений против данной концепции, задался вопросом: «Разве не предпочтительнее вместо того, чтобы говорить о “сдвиге”, подумать о терминах взаимопроникновения (в обе стороны) мифологического и рационального?» [Ibid.: 5].

Вместо того чтобы подробно говорить о пересмотре концепции, от которой мы еще окончательно не освободились (позитивизм по-прежнему присущ научному мышлению в целом, а значит, и антропологии XX — начала XXI в.), будет достаточно сказать несколько слов о предполагаемом главном творце этого сдвига, а именно о Платоне. И оказывается, что мысль того, с чьим именем связывают пик этой великой перемены, буквально пронизана мифологией. По мнению Платона, функция мифа состоит в том, чтобы предложить иную формулировку непознаваемого и непостижимого или невыразимого, а порой и куда более предпочтительную альтернативу философской аргументации:

...но как мне вам это показать: с помощью ли мифа, какие рассказывают старики молодым, или же с помощью рассуждения ( $\mu$ ṽ $\theta$ ov

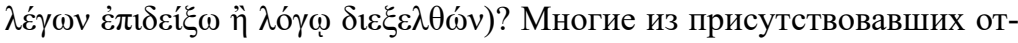
вечали, что, как ему хочется, так пусть и излагает. - Тогда, мне кажется, - решил он, - приятнее будет рассказать вам миф... (Plato. Protag. 320c, пер. В. С. Соловьева). 
Это не окольный путь и не недостаток, а способ сказать о том, где рациональное изложение явно неточно и достигает предела своих возможностей:

Не удивляйся, Сократ, если мы, рассматривая во многих отношениях много вещей, таких, как боги и рождение Вселенной, не достигнем в наших рассуждениях полной точности и непротиворечивости (દiкó $\alpha \varsigma$ ). Напротив, мы должны радоваться, если наше рассуждение окажется не менее правдоподобным, чем любое другое, и притом помнить, что и я, рассуждающий, и вы, мои судьи, всего лишь люди, а потому нам приходится довольствоваться в таких вопросах правдоподобным мифом ( 29cd, пер. С. С. Аверинцева).

Платон демонстрирует явную сдержанность в отношении рационального толкования (см. особ. Rep. 368d5 и Protag. 347e), которое, по его мнению, является «пустой тратой времени» (Phaedr. 229ce) $)^{5}$, говорит об опасности поэтических мифов (Plato. Rep. 377 сл.) и ставит под сомнения содержащиеся в них идеи:

Впрочем, я-то, Федр, считаю, что подобные толкования хотя и при-

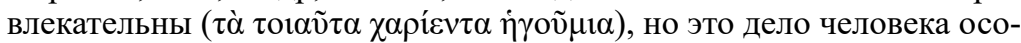
бых способностей; трудов у него будет много, а удачи - не слишком

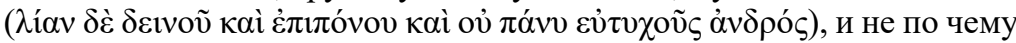
другому, а из-за того, что вслед за тем придется ему восстанавливать подлинный вид гиппокентавров, потом химер, и нахлынет на него целая орава всяких горгон и пегасов и несметное скопище разных других нелепых чудовищ. Если кто, не веря в них, со своей доморощенной мудростью приступит к правдоподобному объяснению

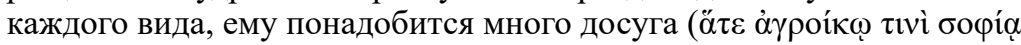

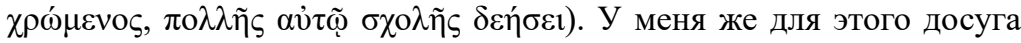
нет вовсе (Plato. Phaedr. 229 ce, пер. А. Н. Егунова).

Однако Платону явно нравится выдумывать мифологические сюжеты и вносить собственный вклад в этот мифологический образ мысли - от мифа о пещере до мифа об Атлантиде, включая развернутый єікஸे $\mu$ ṽ $\theta$ о в виде диалога «Тимей».

\section{Двойственная роль «рационализма»}

Что есть рационалистическое толкование для античной Греции, конкретнее - в связи с прочтением греческих мифов? Очевидно, это перепи сывани е мифа с целью заменить сверхнеобычное содержание приемлемым и таким образом убрать самую суть мифа, сделав его обыкновенной историей. Эта утраченная суть мифа в части сверхъестественного или фантастичного на деле представляет собой второй уровень реальности (на-

${ }^{5}$ О Палефате и этом пассаже см.: [Bouvier 2015: 49-52]. 
зываемый воображением) ${ }^{6}$. По мнению исследователей греческой экзегезы со времен Дж. Тейта [Tate 1927; 1929; 1930], рационализм пагубен для мифов; лишенный сказочной основы как таковой, он привел бы к дискредитации мифа и поощрял бы неверие в богов. Таким образом, рационализм противостоит мифу и способствует эволюции знания. В действительности же он со временем оказался лучшим союзником мифологии. По словам П. Вейна, «критика мифов велась не для демонстрации их лживости, но скорее для того, чтобы найти основание для их правдивости» [Veyne 1983: 69].

Назначение толкований состоит в пере в оде мифа в иной тип дискурса - переводе, который сохраняет его элементы и операционные модели, но меняет его общие исходные рамки и сам регистр повествования. Толкования состоят в смысловом сдвиге. Такая подстановка, в результате которой возникает некий г и пе рм и ф, неизбежно стремится предложить сценарий, повествование или смыслы, которые более сочетаются с реальностью (или, точнее, больше соответствуют представлениям о реальности), и сообщает им видимость истины. В этом отношении можно считать, что все аллегорические толкования, которые, перерабатывая миф, стремятся подтвердить его значимость, но с иной точки зрения, тоже являются разновидностью рациональности ${ }^{7}$. И наоборот, можно утверждать, что рационализация есть разновидность аллегории в современном смысле слова - если подразумевать под ней не сознательное намерение автора, но в принципе тот факт, что текст содержит некое скрытое, вторичное значение ${ }^{8}$. Однако если использовать термин «рационализация» в античном смысле, она должна рассматриваться как вид герменевтики другого рода, нежели аллегория: это скорее своего рода археология мифа, чем его надлежащая интерпретация. В соответствии с рац и о на л и с т и ч е с ко й экзеге зо й (если воспользоваться этим спорным термином) миф является не закодированным изложением некоего более высокого смысла, но испорченным из ложение м более низкой реальности. Р аци она листическая экзегеза - это литературная или лингвистическая интерпретация, состоящая в основном в метонимическом замещении, убирающем сверхъестественные существа и деяния и предлагающем новую версию мифа - а л л о м и ф и ю, отличную от аллегории (см. рис. 1).

Прежде чем обратиться к определенному случаю сюжетного заме щ е н и я, которое является способом толкования самого Палефата, полезно будет дать некоторые разъяснения относительно типологии мифологической экзегезы.

${ }^{6}$ Cм. Plut. Tes. I.3: «Я бы хотел, чтобы сказочный вымысел подчинился разуму и принял видимость настоящей истории. Если же кое-где он со своевольным презрением отвернется от правдоподобия и не пожелает даже приблизиться к нему, просим благосклонного читателя отнестись со снисхождением к этим рассказам о старине» (пер. С. П. Маркиша).

${ }^{7}$ CM.: «...l'allégorie et le symbolisme correspondent à une rationalisation récente de la pensée mythique» («аллегория и символизм соответствуют современной рационализации мифической мысли») [Ре́pin 1958: 67]. О различии между аллегорией и рационализацией см.: [Stern 1996; Govers Hopman 2013: 181].

8 Это позиция М. Говерс Хопман: «Теперь термин “аллегория” используется и в более широком значении, подразумевая любое толкование, которое соотносит текст с некими внетекстовыми смыслами, независимо от вопроса, было ли такое толкование заложено в тексте автором. В широком смысле любая форма герменевтики есть аллегория. В таком широком определении аллегория замещает рационалистическое толкование» [Govers Hopman 2013: 181]. 


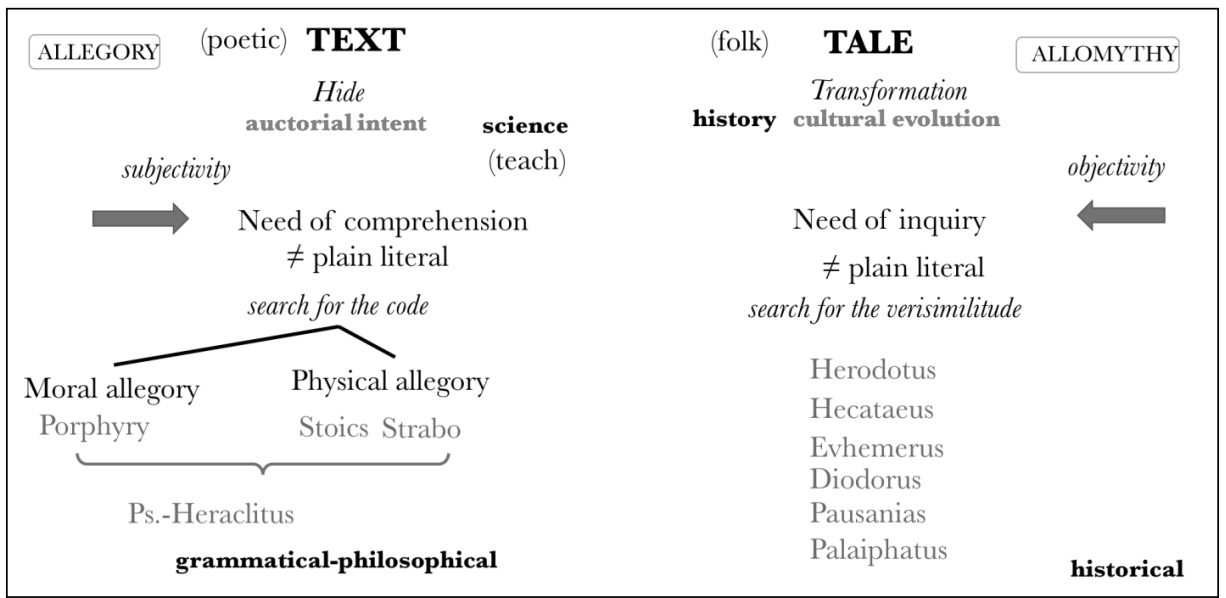

Рис. 1. Консервативная критика мифа

Fig. 1. Conservative criticism of myths

Стандартную типологию предложить сложно; со времен античности существовало много разновидностей сюжетного замещения. Их можно наблюдать у Варрона, Плутарха, Саллюстия, Макробия и др., а до них - также у Аристарха, враждебно настроенного к любой форме аллегорического толкования. Евстафий Солунский сообщал, что он учитывает (как и в нашей схеме) физическую, моральную и

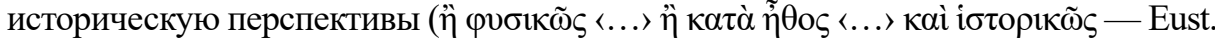
in Il. 1, p. 5, van der Valk). Действительно, можно различать три типа толкований в отношении характерных черт и поступков мифологических персонажей:

1) моральная аллегория: мифологические персонажи отражают психологические особенности;

2) физическая аллегория: мифологические персонажи отражают физическую реальность и реальные явления;

3) историческая аллегория: мифологические персонажи отражают историческую реальность и явления.

Даже не вникая в конкретные детали экзегезы, из приведенной выше схемы сразу видно, что третий тип отличается от первых двух. Действительно, мы имеем, с одной стороны, не фактологическую аллегорию- - закодированный опыт человека (морали) или окружающего мира (физического и географического $)^{9}$; а с другой - фа к тол ог иче ску ю аллегор и ю, рассказ о прошлых (исторических) событиях. Два основных различия состоят в том, что экзегезы 1) трактуют миф либо как текст, либо как сюжет; 2) рассматривают миф как способ рассказывания или как испорченное сообщение.

${ }^{9}$ Cм. Strab. I.2.9.15-18: «Это имеет в виду Гомер, говоря об Одиссее “Так много неправ-

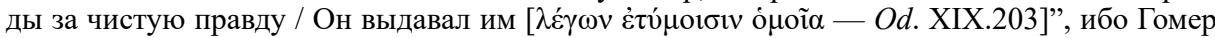
не говорит "всю", но “много" неправды, так как в противном случае она не могла бы сойти за “чистую правду”. Так он взял из истории основу своих рассказов (غ̌ $\lambda \alpha \beta \varepsilon v$ oṽv $\pi \alpha \rho \grave{\alpha} \tau \tilde{\eta} \varsigma$

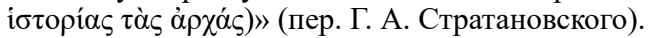




\section{Вопрос рационалистического опыта}

Применительно к практике, о которой идет речь, существуют огромный разнобой и разночтения терминологии: исследователи называют ее рационалистической, но также исторической, реалистической, эвгеме рической, прагматической или веристской. Определение, недавно предложенное М. Говерс Хопман, описывает рационализацию как практику, «которая заменяет сказочные элементы ссылками на реальность 〈...> и как любую интерпретацию мифа, которая соотносит его с элементами повседневного опыта» [Govers Hopman 2013: 180-181]. Это определение неудовлетворительно и слишком расплывчато. Мы допускаем, что можно выделить более специфичный тип комментария или перевода мифа, который переделывает повествование таким образом, что сообщаемые сведения могут соотноситься с историческими событиями, все детали которых отвечают повседневному опыту и законам природы, признаваемым здравым смыслом. Акцент на правдоподобии кажется здесь более главным, чем на рационализме.

Если мы принимаем такое определение, его можно приложить и к античным литературным текстам, восходящим к VI в. до н. э. ${ }^{10}$ На основании наших источников (см.: [Fowler 2000; 2013]) нельзя с точностью определить, каким был подход мифографов или мифологов до V в. до н. э. Однако у нас имеются фрагменты Гекатея Милетского, которые соответствуют такому подходу:

Так говорит Гекатей Милетский: Я пишу это так, поскольку мне представляется это истинным, ибо рассказы эллинов мне кажутся многочисленными и смехотворными (Ps.-Demetrius, Eloc. 12 = Hec. F 1 Fowler, пер. А. В. Лебедева).

По его мнению, Кербер на самом деле - ядовитая змея с мыса Матапан (т. е. Тенарон). По сообщению Павсания, Гекатей полагал, что выдумка о Кербере — просто ошибочное понимание преувеличенной метафоры:

Но Гекатей Милетский нашел правдоподобное объяснение ( $\lambda$ ó $о$ v

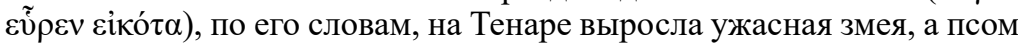
Аида ее прозвали потому, что ужаленного ею ждала немедленная смерть от яда, и вот эту-то змею Геракл и отвел к Еврисфею (Рaus. III.25, 4 = Нес. F 27 Fowler, пер. А. В. Лебедева).

Трактовка Гекатеем Кербера являет пример языковой рационализации чудовищ. Другие авторы, например Акусилай или Ферекид, видимо, обращались к схожим аргументам или исправлениям мифологической традиции. По мнению Говерс Хопман, IV в. до н. э. стал поворотным пунктом: «Критика философов и историков ведет к подъему рационалистических версий, которые приравнивали содержание традиционных повествований к результатам эмпирических наблюдений и в свою очередь оказывали влияние на поздней-

${ }^{10}$ В элегии с советом по организации симпосиев Ксенофан определяет рассказы о борьбе титанов, гигантов или кентавров как «стариковские вымыслы», которые ничего хорошего не принесли слушателям (DK 21 B1, 21-23). 
шие поэтические рассказы» [Govers Hopman 2013: 177]. Однако все античные мифографы имели несколько вариантов про запас. Здесь снова сказывается эффект пластичности греческого подхода и, кажется, ни один ученый не использовал один-единственный метод толкования ${ }^{11}$. Геродор из Гераклеи в VI в. до н. э. использовал несколько способов для того, чтобы «выправить» миф. Он говорил, что Прометей был скифским царем, которого его подданные заковали в цепи, потому что после разлива реки Этос он не смог обеспечить их всем необходимым для жизни. Вмешался Геракл, который изменил русло реки, направив его в море, и освободил царя из заключения (F 30 Fowler). Он основывался на

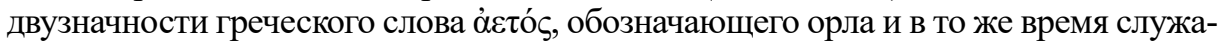
щего названием реки. Однако Геродор использует и другие аллегорические приемы. Так, по его мнению, Геракл должен был убить «змея злого духа при помощи философии, он носил львиную шкуру, что указывало на благородство его души. Более того, яблоки символизировали три доблести, освобождение от злости, жадности и себялюбия» (F 14 Fowler = Io. Antioch. Archeol. 1 F 6, 2 Roberto).

Подход каждого из авторов не ограничивается только одним методом, в их трактовке сюжетов нет никакой системности: не существует текста, предлагающего полную и пословную интерпретацию мифологического сюжета, кроме «Пещеры нимф» Порфирия. Многие детали и элементы не берутся во внимание, даже когда экзегеза касается текста особого статуса, а не обычного повествования (наподобие «Гомеровских аллегорий» Псевдо-Гераклита). В любом случае с самого начала этой традиции понятно, что критика мифов - это в основном критика эпических произведений, и основана она на анализе эпического языка, имеющего две особенности: одна связана с говорящим (поэтом), другая - с самим инструментом (т. е. языком). Поэтическое или, точнее, эпическое повествование склонно преувеличивать количественные характеристики, использовать метафоры, персонифицировать, пренебрегать рамками реальности и т. п. Однако возможность подобных отклонений заложена в самом языке, поскольку он естественно предполагает возможность ошибочных решений и недопонимания, обнаруживая двусмысленность на многих уровнях: полисемию, омонимию, метонимию, сокращения и пр.

\section{Случай Палефата}

\section{Системный подход}

Термин «мифография» (введенный впервые Вестерманном в 1843 г.) имеет двойственную природу: его применяют то к комментаторам мифов, то к простым их соби рателя м (таким как Аполлодор, Антонин Либерал или Псевдо-Гигин) [Alganza Roldán 2006]. Этот второй тип, представителем которого в IV в. до н. э. был Асклепиад, является более поздним, тогда как к первому относятся отдельные авторы уже с VI в. до н. э., в том числе Палефат. Изначально написанное в пяти книгах, его произведение впоследствии было сжато до одной. До его труда под названием «О невероятном» (= «Как читать

${ }^{11} \mathrm{Cp}$.: «[Марсель Детьен] лишний раз продемонстрировал на конкретном примере скудость интерпретаций, пытающихся исчерпать смысл мифов, сводя их к одному коду ‘...> необходимо обращение к нескольким кодам» [Lévi-Strauss 1972: 99-100]: 
мифы») в нашем распоряжении нет ни одного произведения, посвященного интерпретации мифов. Характерный для его труда принцип экзегезы reductio ad sensum communem был достаточно очевиден, всегда под рукой и наверняка время от времени использовался. Но Палефат поставил его на поток.

Следует сказать, что ни при каких обстоятельствах нельзя считать предтечей Палефата Эвгемера. Это невозможно ни с исторической, ни с интеллектуальной точки зрения. Расцвет творчества Эвгемера приходится на 300 г. до н. э., что автоматически делает его моложе Палефата (пик его творчества датируется примерно 330 г. до н. э.). Что до содержания, Эвгемер просто предлагает считать богов людьми, не стремясь при этом к пересмотру мифов. Потому его «Священный список» ничего общего не имеет с нашим текстом [Stern 1996; 1999], поскольку, как уже было отмечено, Палефат концентрируется на героях, а боги его не очень занимают: он попросту обходится без них, не отрицая при этом их существования:

Однако некоторые говорят, будто Артемида превратила Актеона в оленя и что этого оленя разорвали собаки. Однако мне представляется, что Артемида могла поступать как ей угодно ('А

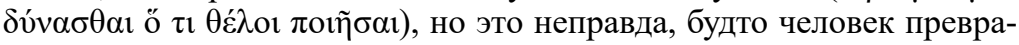
тился в оленя или олень в человека (гл. 6).

В 45 главах своего собрания Палефат предлагает «правдоподобные»

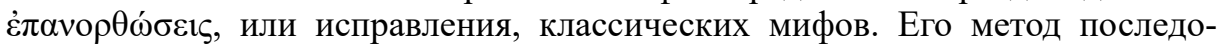
вателен и практически систематичен (что само по себе редкость в античной литературе!). Он подвергает мифологические сюжеты механистической процедуре, представляющей собой четырехступенчатый процесс: 1) изложение краткого содержания традиционного сюжета; 2) его критика с точки зрения правдоподобия; 3) реконструкция предполагаемого сюжета, который положил начало мифу, и демонстрация того, каким образом этот сюжет был испорчен; 4) заключение об искажении повествования.

В итоге из его утверждений и самой экзегетической работы складывается следующее определение мифа: миф - это искаженное в результате неверного описания или порчи нарратива изображение реального исторического опыта. Идеи, лежащие в основе этой концепции и объясняемые в предисловии, можно выразить как набор из трех аксиом: 1) «все рассказанное происходило на самом деле»; 2) «рассказанные истории не просто дополнения к набору имен, но отражают реальные события»; 3) «естественный порядок вещей таков же тогда, как и сейчас». В самом деле, по его мнению, существует непрерывная преемственность между изначальным временем героев и временем людей:

Лично я верю, что все, о чем говорят легенды - правда... историческое событие послужило основой рассказа об этом событии. $\mathrm{Bce,} \mathrm{что} \mathrm{представлено} \mathrm{в} \mathrm{легендах} \mathrm{о} \mathrm{людях,} \mathrm{случалось} \mathrm{так,} \mathrm{как} \mathrm{это}$ и происходит в настоящее время. Ежели бы раньше существовало нечто отличное от того, что существует сейчас, то это нечто существовало бы и сейчас, и в будущем (Предисловие $)^{12}$.

${ }^{12}$ Относительно Предисловия Палефата см. обоснованную критику традиционной ин- 
Оригинальность теории Палефата состоит не в идее, что миф - это правдивое, но искаженное историческое повествование, но в его концепции э т и о -

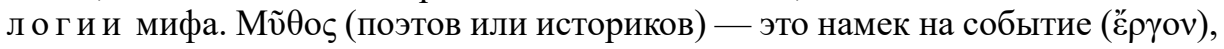

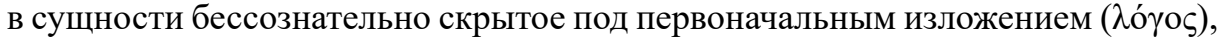
иными словами, сам язык. Действуя в соответствии с основными принципами семиотической археологии, здравомыслящий исследователь может восстановить исходную версию события.

Процессуальный анализ

Мифологическое повествование представляет собой своеобразную языковую патологию. Как полагает Говерс Хопман, «Развитие вымысла объясняется языковым недопониманием, обычно буквальной интерпретацией метафоры или ошибочной трактовкой собственного имени как нарицательного» [Govers Hopman 2013: 182]. Это чрезвычайно похоже на определение мифа в XIX в. Фридрихом Максом Мюллером как «болезни языка».

Палефат, словно врач, идет от симптоматики к реальному нарушению, которое всегда присутствует в языке, по крайней мере по большей части. Таким образом, он должен действовать и как исследователь, разгадывающий загадку: он наматывает нити мифа на бобину реального опыта. Однако миф не случаен и возникает не просто в результате двусмысленного использования языковой метафоры: его порождают двусмысленность и полисемия, которые и сос тавляют сам язык.

В 26 из 45 приводящихся Палефатом примеров текст, по его мнению, сохранил и выделил ключевую фразу, которую Палефат считает формулировкой, породившей исходную проблему. В четырех дополнительных примерах предполагаемое «начальное» предложение мифа парафразируется или дается намеком. Таким образом, можно утверждать, что в двух третях глав дошедшая до нас версия сохранила и суть аргументации, и ключевое звено интерпретации.

Мифологическое высказывание «Пегас, крылатый конь, уносит ввысь Беллерофонта» толкуется как искажение утверждения, в соответствии с которым «Беллерофонт прибыл с Пегасом и разрушил Химеру Амисодара», где Пегас - это корабль, а Химера - гора, подожженная Беллерофонтом (гл. $28)^{13}$. Палефат изменяет (или исправляет) рассказ о спартанцах (гл. 3), пере-

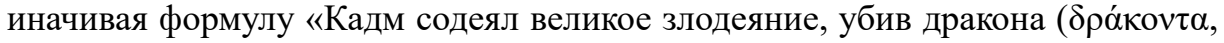

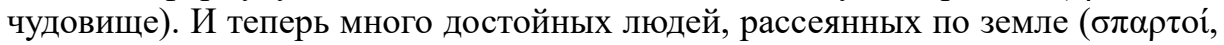

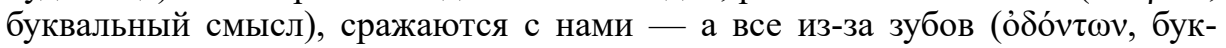
вальный смысл) дракона» на «Кадм содеял великое злодеяние, убив Дракона (царя). И много достойных людей, рассеянных по земле (переносный смысл), сражаются с нами - а все из-за зубов Дракона (бивней слона)».

Большинство семиологических сдвигов - это игры с именами, метонимические или метафорические переносы. Палефат строит свои мифологические

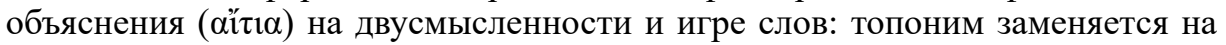
антропоним; зооним или псевдоним, название корабля переносится на человека и т. п. Классический каламбур состоит в смешении человека с именем

терпретации и перевода в [van den Berg 2017]; см. также [Zucker 2016; Santoni 1998/1999].

${ }_{13}$ Ср.: «Рационализация основана на двойственности и неопределенности личных имен» [Govers Hopman 2013: 183]. 
животного с самим животным: Криос («Баран»), Дракон («Змей») или Таврос («Бык»). Правда, не всякая невероятная подробность напрямую соотносится с языком, и в некоторых главах Палефат уделяет внимание трем другим факторам, которые участвуют в создании мифа: во-первых, роли собственно поэтов (prol. 2, 6) ${ }^{14}$, во-вторых - неверному восприятию $(1,32)$; в-третьих неверному переходу от частного к общему $(9,13,14,26,27,43)$. Из-за первого фактора мифологический сюжет с течением времени подвергается порче; два других являются возможной причиной ошибки в изначальном сообщении ${ }^{15}$. На рис. 2 представлена типология семиологических сдвигов, в результате которых, согласно Палефату, рождается мифологический рассказ.

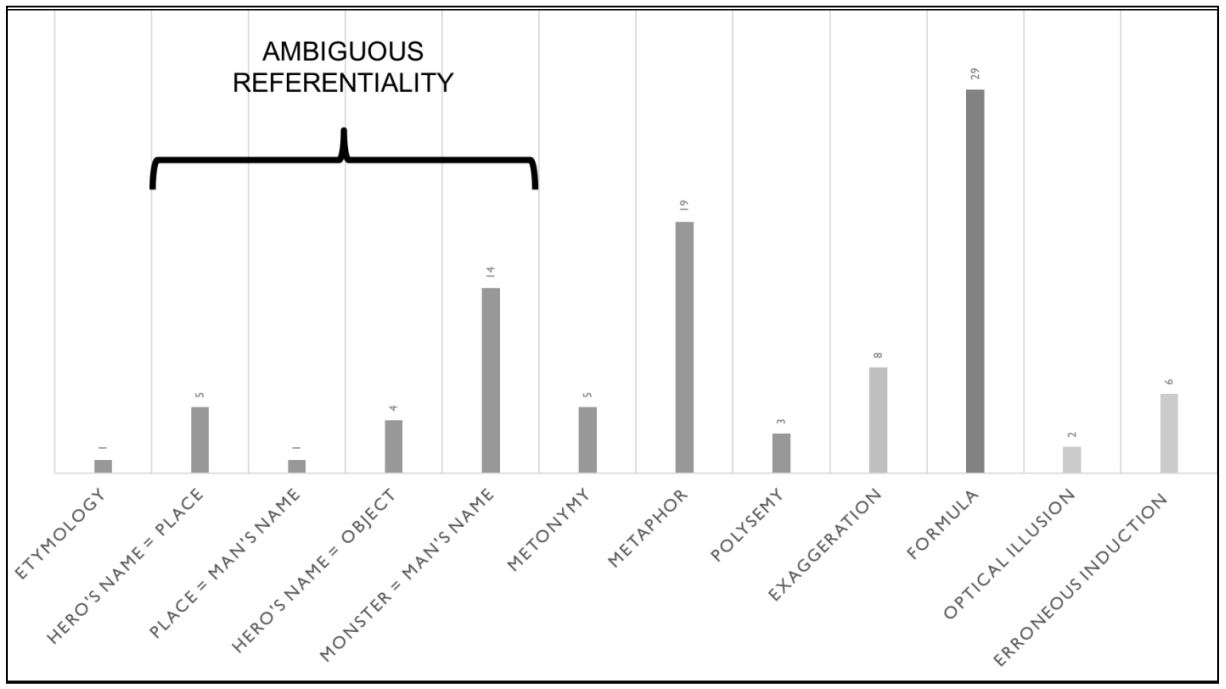

Рис. 2. Лингвистические сдвиги в экзегетической терапии Палефата

Fig. 2. Linguistic shifts in Palaephatus' exegetical therapy

Но при всем этом в большинстве примеров причины обнаруживаются именно в языке, к чему иногда добавляются людские огрехи. Языковые отклонения - не только архаический феномен: они постоянны и потому могут

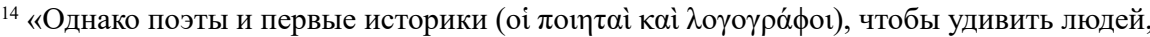
превратили некоторые события прошлого в невероятные и чудесные истории» (прол.); «Таково было событие; но поэты превратили рассказ в миф (вં

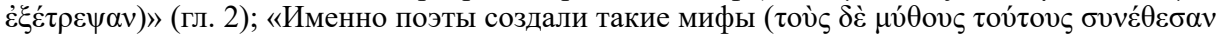
oi $\pi$ oin $\tau \alpha i$ ), чтобы люди, которые слышали их, не стали предпринимать ничего оскорбительного против божеств» (гл. 6).

15 Эти мифогенные факторы участвуют в создании мифа совместно. Так, в первой главе, где нужно расшифровать загадку (или развернуть исходное сообщение), в состав

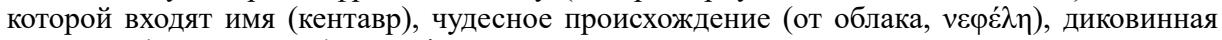
анатомия (человек-конь), Палефат успешно использует этимологию, метонимию, оптическую иллюзию. Первые два приема относятся к грамматике и, соответственно, только они используются для восстановления первичной формулировки мифа. 
воздействовать на повествование всегда и везде. Ведь метафора - это скорее мыслительный механизм, а не чисто языковое явление.

Антропологическая фантазия

В своей реконструкции оригинальных сценариев «событий, превращенных в мифы» Палефат выражает собственную концепцию античной истории; переписанные им мифы напоминают реальную археологию. Человеческий, политический и природный фон архаических времен кажется весьма условным. Схемы Палефата, которыми он заменяет мифологические сценарии, представляют собой простые исторические фантазии и развивают архетипические представления о жизни ранних обществ, где повторяются одни и те же персонажи и последовательности событий, которые представлены на рис. 3.

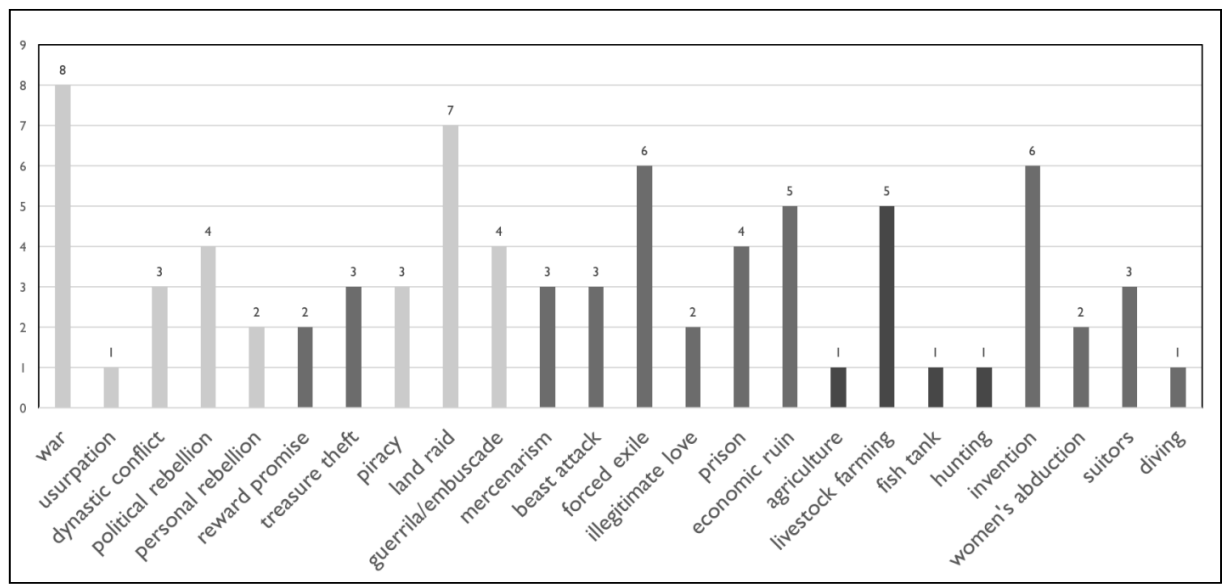

Рис. 3. Типология сюжетов в труде Палефата

Fig. 3. Typology of motives in Palaephatus

Политический режим везде монархический, с выраженным противопоставлением, с одной стороны, сельской природной среды и, с другой, властного центра, который воспринимается как городской, даже если сама городская среда не описывается. Политическая власть сталкивается с тремя типами угрозы: это внешние враги, нападение диких зверей и восстания местного населения или союзников. Эти черты прошлого хорошо соотносятся с политическими и идеологическими рамками традиционного мифологического нарратива. Однако с легкой руки Палефата-«терапевта» они помечены ярлыками «исторические».

Палефат изображает общество без рабов, без денег и скорее сельское: «А жили все люди тогда по деревням, и этим местом и ныне владеют аргивяне. Города же были тогда такие: Аргос, Микены, Тиринф, Лерна, и над каждым из них был поставлен свой царь» (гл. 38); «Люди же тогда все были земледельцами, слуг не имели, сами для себя обрабатывали землю, и тот был самым богатым, кто, возделывая землю, был наиболее трудолюбивым» (гл. 6); «В древности люди были земледельцами и таким образом добывали себе еду» 
(гл. 7); «В те времена люди не сватали себе невест за деньги, а давали кто лошадей, кто волов, кто овец и коз или кто что еще пожелает» (гл. 23); «Впрочем, тогда люди употребляли для этого не деньги, а движимое имущество» (гл. 37); «Деньги тогда не использовали» (гл. 41) (пер. В. Н. Ярхо).

Воскрешение мифа

Палефат мог просто перетолковать элементы известных мифов, однако он стремился создавать новый рассказ, с целостным сюжетом, включающим все эти традиционные элементы. Он не просто «рационализатор мифа» - он заново создает миф на основе древних рассказов.

«В конце концов Палефат - исправитель, он не отвергает мифы, которые получил в наследство. Его произведения говорят о том, что применение разумных оснований к мифу могло иметь первоначальной целью скорее укрепление, а не слабость веры в те же самые мифы и что эти действия не означают безусловного уничтожения muthos» [Stern 1999: 215]. В этом случае «схожесть создает новую версию, дополняя традиционную» [Detienne 1981: 140].

Мифологические элементы, которые воспринимает и исправляет Палефат, более многочисленны, нежели те, которые он прямо перечисляет в кратком пересказе традиционного сюжета. Как кажется, он стремится к полной реконструкции мифа. К примеру, даже если он не упоминает битву Кентавра с Лапифами в главе о Кентаврах (гл. 1), он обращается к ней в реконструируемой им версии, рассказывающей о насилии, исподволь и по-новому связывая все подразумеваемые части сюжета. Переписывание мифа обеспечивает его этиологическую значимость: Палефат, этот новый Гомер, время от времени предлагает свои собственные объяснения ${ }^{16}$.

Жесткость и механистичность метода Палефата, безусловно, впечатляют, а вот тонкости воображения ему, пожалуй, недостает. Если разобрать сплошняком все схемы, которые он предлагает читателю для объяснения весьма разнообразных мифов, то следует признать: набор весьма бедноват! В мифах рассказывается множество разных историй, а их рационалистическое препарирование тяготеет к одной и той же. Алломифия (переписанный сюжет), как и аллегория, свидетельствует об ограниченности воображения, поскольку сводит оригинальную форму к знакомому образцу, заранее известному клише. Метод Палефата с его неизменной систематичностью, помноженной на исторические фантазии, в итоге выхолащивает смысл и превращает миф в пустой трафарет.

Возможно, для Палефата примитивность сюжета - как раз одно из средств убеждения читателя. Он не выбирает наобум, но намеренно останавливается на наиболее банальных, знакомых историях с ожидаемым поворотом событий. Кратко говоря, он превращает миф в своего рода «информационный повод». Именно эту роль предназначает он себе в предисловии — роль р е п о р е ра, который для проведения нового журналистского расследования идет разыскивать свидетелей преступления на месте. Кроме того, с какой настойчивостью

${ }^{16}$ См., например, гл. 30: «Во время путешествия Гелла заболела и умерла: отсюда и название Геллеспонта». 
на протяжении всего произведения Палефат стремится персонализировать свой подход и интерпретацию, характерным образом постоянно прибегая к выражениям типа «мне это не кажется возможным», «я думаю, произошло следующее», «по моему мнению» и т. п.! То, что обычно воспринимается как ссылка на авторитет, можно рассматривать и как указание на приблизительность высказывания. Действительно, текст зачастую подразумевает, что мы имеем дело с некоей правдоподобной реконструкцией, основанной на здравом смысле, с реконструкцией достаточно общей, при этом конкретные де-

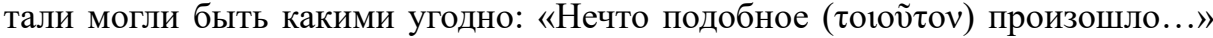
(гл. 2, 5, 6, 13, 21, 26, 31, 38, 43, 44) $)^{17}$. Важно не воссоздать точную последовательность событий, но в целом различить и обосновать исторический повод и предложить семиологическое объяснение (и реинтерпретацию) основных нереалистических черт мифа.

\section{Заключение}

Палефат - единственный античный автор, который методично использует подход, соотносимый со вторым способом интерпретации мифа. Мы называем этот подход а л л м и ф и ей. Он единственный последовательный рационалист, систематически выхолащивающий миф, сводя его детали к историческому анекдоту. Как таковые его роль и текст очень важны. Неудивительно, что до эпохи Ренессанса на него чаще всего ссылались в связи с интерпретациями такого рода. Для исправления двусмысленности и прочих расстройств языка он предлагает терапию - лекарственный коктейль, главным и чуть ли не исключительным элементом которого является анализ семиологических сдвигов. В знаменитой 1-й главе (о Кентаврах, см. недавнее исследование [Alganza Rolda et al. 2017]) проблемы с возникновением мифа можно описать как «плохо увидено, плохо сказано, плохо понято». Но чаще всего причиной становится язык, и только он.

Был ли такой теоретический подход Палефата продиктован каким-то специфическим культурным контекстом? Разброс мнений относительно времени его деятельности (IV или II век до н. э.) [Blumenthal 1942] подразумевает, что его метод легко можно вписать в разные исторические периоды античности, не говоря уже о том, что его произведение многократно цитировали и использовали вплоть до Ренессанса. В Новое время такие археологи, как Генрих Шлиман, или исследователи вроде Виктора Берара обнаруживали не меньшую научную нев инность, и их вполне можно назвать новыми Палефа т а м и: один открыл Трою, второй посетил пещеру Калипсо. Аллегории их не интересовали, а их социально-исторические корни не имели ничего общего с эпохой раннего эллинизма. Просто они были движимы непреодолимым желанием установить неразрывную связь между архаическим повествованием и естественным миром, между вымыслом или воображением и реальностью найти под асфальтом реальности песчаный пляж мифа. Вот и совсем недавно двое исследователей [Baikouzis, Magnasco 2008], опираясь на сведения о

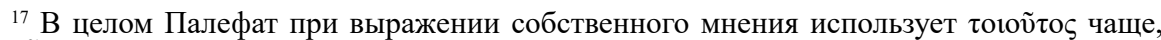

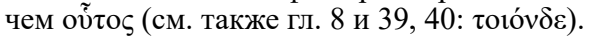


затмениях в «Одиссее» (XX.356-357) и на множество специальных астрономических тонкостей, смогли установить точную дату возвращения Одиссея к Пенелопе - 16 апреля 1178 г. до н. э.

Пер. с англ. Е. В. Илюшечкиной

\section{Литература}

Alganza Roldán 2006 - Alganza Roldán M. La mitografía como género de la prosa helenística: Cuestiones previas // Florentia Iliberritana. Vol. 17. 2006. P. 9-37.

Alganza Roldán et al. 2017 - Alganza Roldán M. A., Barr J., Hawes G. The reception history of Palaephatus 1 (On the Centaurs) in Ancient and Byzantine texts // Polymnia. Vol. 3. 2017. P. 186-235.

Baikouzis, Magnasco 2008 - Baikouzis C., Magnasco M. O. Is an eclipse described in the Odyssey? // Proceedings of the National Academy of Sciences. Vol. 105. No. 26. P. 8823-8828.

Blumenthal 1942 - Blumenthal A. von. Palaiphatos // Paulys Realencyclopädie der classischen Altertumswissenschaft / Hrsg. von G. Wissowa, W. Kroll. Bd. 18.2. Stuttgart: Alfred Druckenmüller Verlag, 1942. Sp. 2449-2455.

Bouveresse 2007 - Bouveresse J. Peut-on ne pas croire: Sur la vérité, la croyance \& la foi. Marseille: Agone, 2007.

Bouvier 2015 - Bouvier D. Palaiphatos ou Le mythe du mythographe // Polymnia. No. 1. 2015. P. $25-60$.

Brisson, Jamme 1996 - Brisson L., Jamme C. Introduction à la philosophie du mythe. Vol. 1: Sauver les mythes. Paris: Librairie Vrin, 1996.

Buffière 1956 - Buffière F. Les mythes d'Homère et la pensée grecque. Paris: Les Belles Lettres, 1956.

Buxton 1999 - Buxton R. Introduction // From myth to reason? Studies in the development of Greek thought / Ed. by R. Buxton. Oxford: Oxford Univ. Press, 1999. P. 1-21.

Detienne 1981 - Detienne M. L'Invention de la mythologie. Paris: Gallimard, 1981.

Fowler 2000 - Fowler R. L. Early Greek mythography. Vol. 1: Text and introduction. Oxford: Oxford Univ. Press, 2000.

Fowler 2013 - Fowler R. L. Early Greek mythography. Vol. 2: Commentary. Oxford: Oxford Univ. Press, 2013.

Gernet 1983 - Gernet L. Les Grecs sans miracle / Textes réunis et présentés par R. Di Donato. Paris: La Découverte, 1983.

Guthrie 1962-1981 - Guthrie W. K. C. A history of Greek philosophy: 6 vols. Cambridge: Cambridge Univ. Press, 1962-1981.

Hopman 2013 - Hopman M. G. Scylla: Myth, metaphor, paradox. Cambridge: Cambridge Univ. Press, 2013.

Lévi-Strauss 1972 - Lévi-Strauss C. M. Detienne. Les jardins d'Adonis: la mythologie des parfums et des aromates en Grèce [compte-rendu] // L'Homme. T. 12. No. 4. P. 97-102.

Nestle 1940 - Nestle $W$. Vom Mythos zum Logos: Die Selbstentfaltung des griechischen Denkens von Homer bis auf die Sophistik und Sokrates. Stuttgart: Alfred Kröner, 1940.

Pépin 1958 - Pépin J. Mythe et allégorie: Les origines grecques et les contestations judéo-chrétiennes. Paris: Études augustiniennes, 1958.

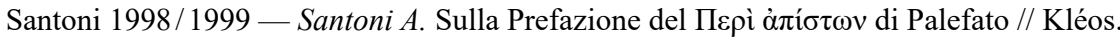
Vol. 2/3. 1998/1999. P. 9-18. 
Stern 1996 - On unbelievable tales: Peri Apiston / Trans., intro., comment. by J. Stern. Wauconda, IL.: Bolchazy-Carducci, 1996.

Stern 1999 - Stern J. Rationalizing myth: Methods and motives in Palaephatus // From myth to reason?: Studies in the development of Greek thought / Ed. by R. Buxton. Oxford: Oxford Univ. Press, 1999. P. 215-222.

Tate 1927 - Tate J. The beginnings of Greek allegory // The Classical Review. Vol. 41. No. 6. 1927. P. 214-215.

Tate 1929 - Tate J. Plato and Allegorical Interpretation // The Classical Quarterly. Vol. 23. No. 3-4. 1929. P. 142-154.

Tate 1930 - Tate J. Plato and Allegorical Interpretation (Continued) // The Classical Quarterly. Vol. 24. No. 1. 1930. P. 1-10.

van den Berg 2017 - van den Berg R. M. Palaephatus on ỏvó $\mu \alpha \tau \alpha, \lambda o ́ \gamma o$, and है $\rho \gamma \alpha / /$ Mnemosyne. Vol. 70. No. 2. 2017. P. 308-315.

Vernant 1962 - Vernant J. P. Les origines de la pensée grecque. Paris: Presses universitaires de France, 1962.

Veyne 1983 - Veyne P. Les grecs ont-ils cru à leurs mythes? Essai sur l'imagination constituante. Paris: Seuil, 1983.

Zucker 2016 - Zucker A. Palaiphatos ou la clinique du mythe // Lire les mythes: Formes, usages et visées des pratiques mythographiques de l'Antiquité à la Renaissance / Sour la dir. de A. Zucker, J. Fabre-Serris, J.-Y. Tilliette, G. Besson. Villeneuve-d'Ascq: Presses Univ. du Septentrion. 2016. P. 43-66.

\section{References}

Alganza Roldán, M. (2006). La mitografía como género de la prosa helenística: Cuestiones previas. Florentia Iliberritana, 17, 9-37. (In Spanish).

Alganza Roldán, M. A., Barr, J., Hawes, G. (2017). The reception history of Palaephatus 1 (On the Centaurs) in Ancient and Byzantine texts. Polymnia, 3, 186-235.

Baikouzis, C., Magnasco, M. O. (2008). Is an eclipse described in the Odyssey? Proceedings of the National Academy of Sciences, 105(26), 8823-8828.

Blumenthal, A. von (1942). Palaiphatos. In G. Wissowa, W. Kroll (Eds.). Paulys Realencyclopädie der classischen Altertumswissenschaft (Vol. 18.2), 2449-2455. Stuttgart: Alfred Druckenmüller Verlag.

Bouveresse, J. (2007). Peut-on ne pas croire: Sur la vérité, la croyance \& la foi. Marseille: Agone. (In French).

Bouvier, D. (2015). Palaiphatos ou Le mythe du mythographe. Polymnia, 1, 25-60. (In French).

Brisson, L., Jamme, C. (1996). Introduction à la philosophie du mythe, (Vol. 1) Sauver les mythes. Paris: Librairie Vrin. (In French).

Buffière, F. (1956). Les mythes d'Homère et la pensée grecque. Paris: Les Belles Lettres. (In French).

Buxton, R. (1999). Introduction. In R. Buxton (Ed.). From myth to reason? Studies in the development of Greek thought, 1-21. Oxford: Oxford Univ. Press.

Detienne, M. (1981). L'Invention de la mythologie. Paris: Gallimard. (In French).

Fowler, R. L. (2000). Early Greek mythography, (Vol. 1) Text and introduction. Oxford: Oxford Univ. Press.

Fowler, R. L. (2013). Early Greek mythography, (Vol. 2) Commentary. Oxford: Oxford Univ. Press.

Gernet, L. (1983). Les Grecs sans miracle (R. Di Donato, Ed.). Paris: La Découverte. (In French).

Guthrie, W. K. C. (1962-1981). A history of Greek philosophy (6 Vols.). Cambridge: Cambridge Univ. Press. 
Hopman, M. G. (2013). Scylla: Myth, metaphor, paradox. Cambridge: Cambridge Univ. Press.

Lévi-Strauss, C. (1972). [Review of the book Les jardins d'Adonis: la mythologie des parfums et des aromates en Grèce by M. Detienne]. L'Homme, 12(4), 97-102. (In French).

Nestle, W. (1940). Vom Mythos zum Logos: Die Selbstentfaltung des griechischen Denkens von Homer bis auf die Sophistik und Sokrates. Stuttgart: Alfred Kröner. (In German).

Pépin, J. (1958). Mythe et allégorie: Les origines grecques et les contestations judéo-chrétiennes. Paris: Études augustiniennes. (In French).

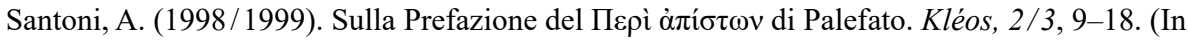
Italian).

Stern, J. (Trans., Intro., Comment.) (1996). On unbelievable tales: Peri apiston. Wauconda, IL.: Bolchazy-Carducci

Stern, J. (1999). Rationalizing myth: Methods and motives in Palaephatus. In R. Buxton (Ed.). From Myth to reason?: Studies in the development of Greek thought, 215-222. Oxford: Oxford Univ. Press.

Tate, J. (1927). The beginnings of Greek allegory. The Classical Review, 41(6), 214-215.

Tate, J. (1929). Plato and Allegorical Interpretation. The Classical Quarterly, 23(3-4), 142-154.

Tate, J. (1930). Plato and Allegorical Interpretation (Continued). The Classical Quarterly, 24(1), 1-10.

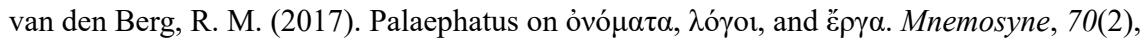
308-315.

Vernant, J. P. (1962). Les origines de la pensée grecque. Paris: Presses universitaires de France. (In French).

Veyne, P. (1983). Les grecs ont-ils cru à leurs mythes? Essai sur l'imagination constituante. Paris: Hachette. (In French).

Zucker, A. (2016). Palaiphatos ou la clinique du mythe. In A. Zucker, J. Fabre-Serris, J.-Y. Tilliette, G. Besson (Eds.). Lire les mythes: Formes, usages et visées des pratiques mythographiques de l'Antiquité à la Renaissance, 43-66. Villeneuve-d'Ascq: Presses Univ. du Septentrion. (In French).

\section{Информация об авторе}

\author{
Арно Зукер \\ $P h D$ \\ npoфeccop, \\ Cultures - Environnements. Préhistoire, \\ Antiquité, Moyen Âge (CEPAM), \\ Начиональный иентр научных \\ исследований (CNRS), \\ Университет Лазурного берега \\ (Université Côte d'Azur) \\ Pôle Universitaire Saint Jean d'Angély (SJA 3), \\ France, 06357, Nice Cedex 4, \\ 24 Avenue des Diables Bleus \\ Тел.: +33 (0) 4-89152385 \\ arnaud.zucker@univ-cotedazur.fr
}

$$
* * *
$$

\section{Information about the author}

\section{Arnaud Zucker}

$P h D$

Professor (Greek Philology),

Cultures - Environnements. Préhistoire,

Antiquité, Moyen Âge (CEPAM),

The French National Centre for Scientific

Research (CNRS),

University of Côte d'Azur

Pôle Universitaire Saint Jean d'Angély (SJA 3),

France, 06357, Nice Cedex 4,

24 Avenue des Diables Bleus

Tel.: +33 (0) 4-89152385

arnaud.zucker@univ-cotedazur.fr 